\title{
Monoclonal Antibodies Specific to the $\beta$ and $\gamma$ Subunits of the Torpedo Acetylcholine Receptor Inhibit Single-Channel Activity
}

\author{
Yoav Blatt, ${ }^{\star}$ Myrta S. Montal, ${ }^{\star}$ Jon M. Lindstrom, $†$ and Mauricio Montal* \\ *Departments of Biology and Physics, University of California San Diego, La Jolla, California 92093, and \\ †The Salk Institute for Biological Studies, San Diego, California 92138
}

\begin{abstract}
The functional role of individual ACh receptor subunits in the mechanism of the nicotinic $\mathrm{ACh}$ receptor channel was examined using subunit-specific monoclonal antibodies (mAbs) as probes. Single-channel recordings from the Torpedo californica purified $A C h$ receptor reconstituted in planar lipid bilayers were used as the assay to evaluate the influence of distinct $\mathrm{mAbs}$ on the ion conduction and gating characteristics of the ACh receptor channel. The mAbs that bind to the main immunogenic region on an extracellular domain of the $\alpha$ subunits do not perturb the open-channel conductance or lifetimes. A mAb that binds to extracellular domains of $\alpha$ and $\beta$ subunits and two mAbs that bind to the cytoplasmic surface of the $\beta$ and $\gamma$ subunits inhibit single-channel activity. Thus, $m A$ bs with primary specificity for $\beta$ and $\gamma$ subunits affect channel gating. This approach may specify the functional roles of distinct structural domains in the $\mathrm{ACh}$ receptor molecule.
\end{abstract}

The nicotinic ACh receptor from Torpedo californica consists of four structurally homologous subunits in the mole ratio $\alpha_{2} \beta \gamma \delta$ (cf. Changeux et al., 1984). All four ACh receptor subunits are transmembrane polypeptides (Froehner, 1981; Strader and Rafferty, 1980; Strader et al., 1979; Tarrab-Hazdai et al., 1978; Wennogle and Changeux, 1980), and the complete amino acid sequences of all four subunits have been deduced from the nucleotide sequences of cDNA clones (Claudio et al., 1983; Devillers-Thiery et al., 1983; Noda et al., 1982, 1983a, b). Reconstitution of the purified ACh receptor in lipid vesicles (Anholt et al., 1981, 1982; Changeux et al., 1979; Gonzalez-Ros et al., 1980; Huganir et al., 1979; Lindstrom et al., 1980; Wu and Raftery, 1979) and in lipid bilayers (Boheim et al., 1981; Labarca et al., 1984a, b; Nelson et al., 1980; Schindler et al., 1984; Tank et al., 1983) demonstrated that the $\alpha_{2} \beta \gamma \delta$ structure is sufficient to express the transduction of ligand binding into the opening of a cation-specific channel. Expression of functional ACh reccptor in Xenopus oocytes directed by the cloned cDNAs encoding the four subunits of the ACh receptor indicated that

\footnotetext{
Received Apr. 22, 1985; revised June 24, 1985; accepted July 3, 1985.

We are indebted to Tony Lee and Richard Greenblatt for their assistance with the computer programs, Douglas Schneider for technical assistance, and Kee Wan for sharing with us his data on reconstituted $\mathrm{ACh}$ receptor in vesicles. This research was supported by grants from the National Institutes of Health (EY-02084 to M.M. and NS-1 1323 to J.L.), the Department of the Army Medical Research (1782-C2221 to M.M.), the Muscular Dystrophy Association, the Los Angeles and California chapters of the Myasthenia Gravis Foundation, the Alexander S. Onassis Charitable Foundation, and the McKnight Foundation (to J.L.). Part of this investigation was performed while Y.B. was a postdoctoral fellow of the Muscular Dystrophy Association of America.

Correspondence should be addressed to Dr. Mauricio Montal at his present address: Department of Neurosciences, Roche Institute of Molecular Biology, Nutley, NJ 07110.
}

Copyright (c) 1986 Society for Neuroscience $0270-6474 / 86 / 020481-06 \$ 02.00 / 0$ all four subunits are necessary to exhibit the cholinergic response (Mishina et al., 1984). However, a fundamental question remains concerning the functional specificity of individual $\mathrm{ACh}$ receptor subunits in channel function. The $\alpha$ subunits contain the two ACh binding sites (Kao et al., 1984; Mishina et al., 1985 ), and it is thought that $\alpha \beta \gamma$ and $\delta$ subunits all contribute to the structure of the cation channel (Changeux et al., 1984).

Monoclonal antibodies (mAbs) directed against determinants in specific ACh receptor subunits (Donnelly et al., 1984; Goldberg et al., 1983; Gullick and Lindstrom, 1983; Hochschwender et al., 1985; Lindstrom et al., 1981a, b, 1983; Sargent et al., 1984; Tzartos and Lindstrom, 1980, 1981; Tzartos et al., 1981, in press; Wan and Lindstrom, 1985) are being extensively used to map the distribution of nicotinic receptors in nervous tissues and inside neurons, to purify and characterize these receptors (Lindstrom et al., 1983), and to identify transmembrane quaternary arrangements of the five receptor subunit polypeptides as a first step toward a low-resolution structure of the $\mathrm{ACh}$ receptor protein (Criado et al., 1985a, b; Young et al., 1985). In this study, mAbs are used as probes for the functional specificity of individual $\mathrm{ACh}$ receptor subunits in the mechanism of the ACh-regulated cation channel. The novelty of this approach resides in the use of single-channel recordings from the T. californica purified $\mathrm{ACh}$ receptor reconstituted in lipid bilayers to examine the ability of $\mathrm{mAbs}$ to alter the ion conduction and gating characteristics of the $\mathrm{ACh}$ receptor channel (Labarca et al., 1984a, b; 1985a, b; Montal et al., 1984; Suarez-Isla et al., 1983). We report that $\mathrm{mAbs}$ that bind to the main immunogenic region (MIR) on an extracellular domain of the $\alpha$ subunits do not perturb the open-channel conductance or lifetimes. $\mathrm{A}$ mAb that binds to extracellular domains of $\alpha$ and $\beta$ subunits and two $\mathrm{mAbs}$ that bind to the cytoplasmic surface of the $\beta$ and $\gamma$ subunits, inhibit single-channel activity. Thus, $m A$ bs with primary selectivity for $\beta$ and $\gamma$ subunits affect channel gating. This approach may specify the functional roles of distinct structural domains in the $\mathrm{ACh}$ receptor molecule. Preliminary accounts of this research were presented elsewhere (Blatt et al., 1984; Lindstrom et al., 1983).

\section{Materials and Methods}

\section{$A C h$ receptor preparation}

Receptor from the electric organ of $T$. californica (Pacific Bio-Marine Laboratorics, Inc., Vcnicc, CA) was solubilized, purificd, rcconstituted in lipid vesicles, and assayed as described in detail elsewhere (Anholt et al., 1981, 1982; Lindstrom et al., 1980). The reconstituted soybean lipid vesicles $(32 \mathrm{mg} / \mathrm{ml})$ were supplemented with cholesterol $(8 \mathrm{mg} /$ $\mathrm{ml})$. The ACh receptor concentration in the vesicles ranged between 0.2 and $1.0 \mu \mathrm{M}$. 


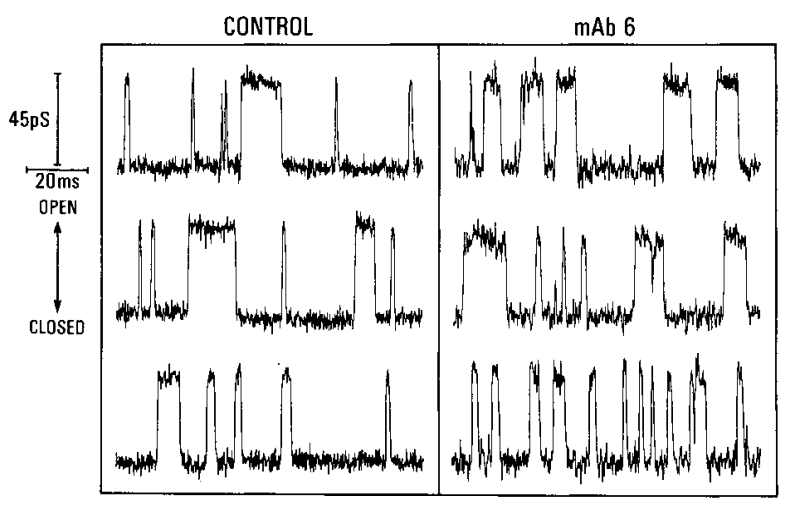

Figure 1. Anti-MIR mAb 6 does not affect ACh receptor single-channel currents. Single ACh receptor channel currents were activated by 10 $\mu_{\mathrm{M}} \mathrm{ACh}$ in the absence (left-hand panel) and presence (right-hand panel) of anti-receptor $\mathrm{mAb} 6$. The recordings were obtained at an applied voltage of $100 \mathrm{mV}$. As indicated, an upward deflection corresponds to a channel-opening event. The open-channel conductance was $45 \mathrm{pS}$ in both conditions. The mAb 6 was added to the same compartment as the ACh (cis) to a final concentration of $1.4 \mu \mathrm{M}$. ACh receptor concentration was $0.07 \mu \mathrm{M}$. The recordings were obtained from bilayers formed at the tip of patch pipets. The seal resistance was $10 \mathrm{G} \Omega$.

\section{Monoclonal antibodies specific to ACh receptor subunits}

MAbs were prepared by fusion of spleen cells from immunized rats with mouse or rat myeloma cell lines as previously described (Lindstrom et al., 1981a; Tzartos and Lindstrom, 1980, 1981; Tzartos et al., 1981). The IgG fractions were precipitated from culture supernatants by $45 \%$ saturation ammonium sulfate and dialyzed against phosphate buffer $\left(0.15 \mathrm{M} \mathrm{NaCl}, 0.01 \mathrm{~m}\right.$ sodium phosphate, $0.01 \mathrm{~m} \mathrm{NaN}_{3}$, pH 7.4). The mAbs were affinity purified by adsorption on to goat anti-rat IgG Sepharose CL-4B; mAbs were eluted with $0.1 \mathrm{M}$ triethylamine, $\mathrm{pH} 11.5$, dialyzed against phosphate buffer, concentrated by ultrafiltration (Amicon) and the titer was determined (Lindstrom et al., 1981a; Wan and Lindstrom, 1985). Receptor subunit specificity was determined by radioimmunoassay using ${ }^{125}$ I-labeled subunits (Gullick and Lindstrom, 1983; Tzartos and Lindstrom, 1980) and also by (ELISA) assays (Hochschwender et al., 1985). Transmembrane orientation of the mAb binding sites was measured by histochemical methods on frog muscle (Sargent et al., 1984), by immune precipitation and ELISA assays (Hochschwender et al., 1985), and by binding to native ACh receptor vesicles (Wan and Lindstrom, 1985). Fab fragments were produced by papain proteolysis (mAb: papain, 100:1, w/w), dialyzed, concentrated, and titer determined as described (Wan and Lindstrom, 1985).

\section{Single-channel recording and data processing}

Monolayers at the air-water interface were derived from suspensions of reconstituted ACh receptor vesicles (Anholt et al., 1982) as described in detail (Labarca et al., 1984a). The vesicles were diluted 6-fold in the bilayer chamber. Planar lipid bilayers were assembled from two such monolayers across apertures in Teflon septi (Labarca et al., 1984a, b;
Montal et al., 1984; Nelson et al., 1980) or at the tip of patch pipets (Labarca et al., 1985a, b; Montal et al., 1984; Suarez-Isla et al., 1983). Bilayers were formed and studied in $0.5 \mathrm{M} \mathrm{NaCl}, 5 \mathrm{mM} \mathrm{CaCl}_{2}$, and 2.5 mM Tricine ( $N$-Tris [hydroxymethyl] methylglycine) or HEPES buffer, pH 7.4.

Single-channel currents were activated by ACh added to one side of the membrane (cis-side) and recorded as described in detail elsewhere (Labarca et al., 1984a, b; Suarez-Isla et al., 1983). A List EPC-7 patch clamp system was also used (List Medical Electronics, Darmstadt, F.R.G.). The recordings were filtered at $2 \mathrm{kHz}$ (8-pole Bessel filter) and digitized at a sampling rate of $10 \mathrm{kHz}$ in a PDP $11 / 34$ computer. Records in which only one channel was open at any given time were analyzed. Histograms of dwell times in the open state of $\mathrm{ACh}$ receptor channel, normalized to have a total area equal to one, were well-fitted by a probability density function of the form $N(t)=A_{S} \exp \left(-t / \tau_{S}+A_{L}\right.$. $\exp \left(-t / \tau_{l}\right)$ using a $\chi^{2}$ minimization algorithm (Fletcher, 1971) giving $p$ values $\geq 0.8$ (Labarca et al., 1985a, b). The single-channel conductance was calculated from conductance histograms fitted by the sum of two Gaussian functions corresponding to closed- and open-channel states (Labarca et al., 1984a).

The effects of the antibodies were studied by (1) incubating the reconstituted vesicles with antibody for $20 \mathrm{~min}$ at $4^{\circ} \mathrm{C}$ at a $4-40$-fold molar excess prior to bilayer formation; or (2) by addition of antibody to a bilayer during periods of channel activity elicited by ACh. All the experiments were performed at room temperature $\left(22 \pm 2^{\circ} \mathrm{C}\right)$.

\section{Results and Discussion}

The properties of the mAbs characterized in this study are summarized in Table 1. A detailed description appears elsewhere (Gullick and Lindstrom, 1983; Hochschwender et al., 1985; Lindstrom et al., 1981a, b, 1983; Sargent et al., 1984; Tzartos and Lindstrom, 1980, 1981; Tzartos et al., 1981, in press; Wan and Lindstrom, 1985). None of these mAbs bind to the ACh binding site. $\mathrm{A}$ few mAbs block the function of $\mathrm{ACh}$ receptor when studied by the $\mathrm{Na}^{+}$flux assay in reconstituted vesicles (Lindstrom et al., 1981b, 1983; Wan and Lindstrom, 1985). The detailed identification of the inhibitory effects of mAbs on the $\mathrm{ACh}$ receptor channel can be further investigated in reconstituted planar lipid bilayers, where the ion conduction and gating characteristics of the purified $\mathrm{ACh}$ receptor channel are readily measurable (Boheim et al., 1981; Labarca et al., 1984a; Nelson et al., 1980; Schindler et al., 1984; Tank et al., 1983). This is illustrated in the left-hand panel of Figure 1. Three sections from a continuous record of single-channel currents activated by $10 \mu \mathrm{M} \mathrm{ACh}$ at a constant applied voltage of $100 \mathrm{mV}$ are illustrated. Two distinct channel states are clearly discerned, corresponding to the closed and open states of the channel. Transitions between closed and open states are indicated by the arrows. The single-channcl conductance was $45 \mathrm{pS}$ (in $0.5 \mathrm{M}$ $\mathrm{NaCl}$ ) as calculated from conductance histograms (not shown, see Labarca et al., 1984a).

Both mAb 6 and $\mathrm{mAb} 35$ bind to the main immunogenic region on the extracellular domain of the $\alpha$ subunit, away from

Table 1. Monoclonal antibodies used in this study

\begin{tabular}{|c|c|c|c|c|c|c|}
\hline $\mathrm{mAb}$ & $\begin{array}{l}\text { Subunit } \\
\text { specificity }\end{array}$ & $\begin{array}{l}\text { Transmembrane } \\
\text { orientation of } \\
\text { binding site }\end{array}$ & $\begin{array}{l}\text { Type of Ab-AChR } \\
\text { complex formed }{ }^{a}\end{array}$ & Immunogen & $\begin{array}{l}\text { Affinity } \\
\left(K_{\mathrm{d}}, \mathrm{nM}\right)\end{array}$ & Ref. $^{b}$ \\
\hline 6 & $\alpha$, MIR & Extracellular & $2 \mathrm{Ab} / \mathrm{AChR}$ & Native AChR (Torpedo) & 0.3 & $1-4$ \\
\hline 35 & $\alpha$, MIR & Extracellular & $2 \mathrm{Ab} / \mathrm{AChR}$ & Native AChR (Electrophorus) & 2 & 1,5 \\
\hline 10 & $\beta($ also $\alpha)$ & Extracellular & $1 \mathrm{Ab} / \mathrm{AChR}$ & Denatured AChR (Torpedo) & 15 & $1-3$ \\
\hline 148 & $\beta$ & Cytoplasmic & $1 \mathrm{Ab} / \mathrm{AChR}$ & Denatured AChR (Torpedo) & 2.7 & $3,6,7$ \\
\hline 168 & $\gamma$ & Cytoplasmic & $1 \mathrm{Ab} / \mathrm{AChR}$ & Denatured AChR (Torpedo) & 18 & $3,6,7$ \\
\hline 7 & $\delta($ also $\gamma)$ & Cytoplasmic & $1 \mathrm{Ab} / \mathrm{AChR}$ & Denatured AChR (Torpedo) & 1.6 & $1-4$ \\
\hline
\end{tabular}

${ }^{a} \mathrm{Ab}-\mathrm{ACh}$ receptor complex formed at high $\mathrm{Ab}$ to $\mathrm{AChR}$ ratio, a condition similar to that used in this study. AChR denotes $\mathrm{ACh}$ receptor.

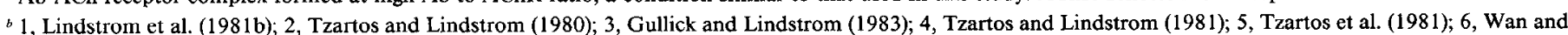
Lindstrom (1985); 7, Tzartos et al. (in press). 
Table 2. Effect of antireceptor mAbs and their Fab fragments on the single-channel conductance of reconstituted Torpedo $\mathrm{ACh}$ receptor

\begin{tabular}{cl}
$\mathrm{mAb}$ & $\begin{array}{l}\text { Open-channel } \\
\text { conductance }(\mathrm{pS})\end{array}$ \\
\hline None & $46 \pm 6(n=29)$ \\
$35 \mathrm{Fab}$ & $45 \pm 5(n=6)$ \\
6 & $47 \pm 5(n=10)$ \\
$148 \mathrm{Fab}$ & $44 \pm 5(n=6)$ \\
$168 \mathrm{Fab}$ & $44 \pm 5(n=6)$ \\
7 & $46 \pm 6(n=10)$
\end{tabular}

Membrances were formed in $0.5 \mathrm{M} \mathrm{NaCl}, 5 \mathrm{~mm} \mathrm{CaCl}_{2}$, and 2.5 mm Tricine or HEPES, pH 7.4. ACh receptor channels were activated with $10 \mu \mathrm{M}$ ACh and recorded at $100 \mathrm{mV}$. The tabulated values are the single-channel conductance \pm $\mathrm{SD}(n=$ number of experiments).

the ACh binding site (Lindstrom et al., 1981b). Single-channel current recordings obtained in the presence of a 20 -fold molar excess of $\mathrm{mAb} 6$ are shown in the right-hand panel of Figure 1. Inspection of the records reveals no change in single-channel conductance (Table 2); nor were the frequency or the pattern of occurrence of the single events altered.

To assess quantitatively the effect of anti-MIR mAbs on the kinetics of channel gating, the lifetimes of the $\mathrm{ACh}$ receptor channel in the open state were analyzed. Previous analysis of single-channel records of the reconstituted ACh receptor demonstrated that the ACh receptor channel has two, kinetically distinct, open states (Labarca et al., 1984a, b; Montal et al., 1984; Suarez-Isla et al., 1983). Probability density analysis of dwell times in the open state of the $\mathrm{ACh}$ receptor channel in the presence of mAbs 6 and 35 shows that the data are also well-fitted by a sum of two exponentials. The results of this analysis are summarized in Table 3. The amplitudes $(A)$ and the time constant $(\tau)$ values for the exponential components of the short (S) and long (L) kinetic processes involved in channel closure are virtually unaltered by mAbs 6 and 35. The results obtained with Fab 35, the monovalent antigen binding fragment, were equivalent (Tables 2 and 3). Two other cholinergic agonists were also used, namely, carbamylcholine $(400 \mu \mathrm{M})$ and suberyldicholine $(10 \mu \mathrm{M})$, and the results obtained were analogous (see also Lindstrom et al., 1983). Thus, anti-MIR mAbs altered neither the ion conduction through the $\mathrm{ACh}$ receptor channel nor its gating characteristics. This result is significant, since this is the most frequent autoantibody specificity in myasthenia gravis patients (Tzartos et al., 1982) and implies that such autoantibodies impair neuromuscular transmission, primarily through antigenic modulation and complement-mediated focal lysis (Lindstrom et al., 1983; Tzartos et al., 1982).

In contrast, three mAbs directed against determinants in the $\beta$ and $\gamma$ subunits inhibited channel activity. This is illustrated in Figure 2. MAb 10, which binds to an extracellular domain of the $\beta$ subunit and also cross-reacts with the $\alpha$ subunit (Lindstrom et al., 1981b; Tzartos and Lindstrom, 1980), caused inhibition of the ACh receptor channel when added to the same compartment as ACh (Fig. 2A, Table 4). MAb 148, which recognizes a domain on the cytoplasmic surface of the $\beta$ subunit, inhibited single $A C h$ receptor channel activity only when added to the compartment opposite that containing $\mathrm{ACh}$, as would be expected from its known specificity for a determinant on the cytoplasmic surface of the receptor (Wan and Lindstrom, 1985) (Fig. 2B, Table 4). MAb 168, directed against a domain on the cytoplasmic surface of the $\gamma$ subunit, also inhibited channel activity only when added to the compartment opposite that containing ACh (Fig. $2 C$, Table 4), in agreement with its specificity for a cytoplasmic domain (Wan and Lindstrom, 1985) (Table 1). MAb 10 was previously shown (Lindstrom et al.,
Table 3. Effect of mAb 35 and mAb 6 on the open-channel gating kinetics of reconstituted Torpedo ACh receptor

\begin{tabular}{llll} 
& Control & $\mathrm{mAb} 35$ & $\mathrm{mAb} 6$ \\
\hline$A_{\mathrm{S}}$ & $0.70 \pm 0.06$ & $0.71 \pm 0.08$ & $0.69 \pm 0.17$ \\
$\tau_{\mathrm{S}}$ & $0.63 \pm 0.19 \mathrm{~ms}$ & $0.62 \pm 0.30 \mathrm{~ms}$ & $0.64 \pm 0.40 \mathrm{~ms}$ \\
$A_{\mathrm{L}}$ & $0.30 \pm 0.06$ & $0.29 \pm 0.08$ & $0.31 \pm 0.18$ \\
$\tau_{\mathrm{L}}$ & $4.3 \pm 1.5 \mathrm{~ms}$ & $4.1 \pm 2.1 \mathrm{~ms}$ & $4.3 \pm 1.6 \mathrm{~ms}$ \\
$n$ & 25,725 & 39,192 & 8774
\end{tabular}

Membranes were formed in $0.5 \mathrm{M} \mathrm{NaCl}, 5 \mathrm{mM} \mathrm{CaCl}_{2}, 2.5 \mathrm{~mm}$ Tricine or HEPES, $\mathrm{pH}$ 7.4. ACh receptor single-channel currents were activated by $10 \mu \mathrm{M} \mathrm{ACh}$ and recorded at $100 \mathrm{mV}$. The amplitudes $A_{\mathrm{S}}$ and $A_{\mathrm{L}}$, and the time constants $\tau_{\mathrm{S}}$ and $\tau_{\mathrm{L}}$, of the exponential fit obtained by a $\chi^{2}$ minimization algorithm (Fletcher, 1971 . Labarca et al., 1985a, b) are tabulated. $S$ and $L$ refer to the short and long kinetic processes; $n$ is the total number of events analyzed. MAb 35 Fab and mAb 6 were added to a final concentration of 0.4 and $1.2 \mu \mathrm{M}$, respectively. The ACh receptor concentration was between 0.02 and $0.09 \mu \mathrm{M}$.

$1981 \mathrm{~b}, 1983)$ to inhibit the carbamylcholine-activated influx of ${ }^{22} \mathrm{Na}^{+}$into reconstituted vesicles when added after their formation. In contrast, mAbs 148 and 168 inhibited the flux response only if present during the vesicle reassembly process, implying that inhibition was caused by binding to a domain on the cytoplasmic surface of the ACh receptor (Lindstrom et al., 1983; Wan and Lindstrom, 1985).

MAbs 10,148 , and 168 drastically reduced channel activity. The few remaining events had the same channel properties as those present before the addition of $\mathrm{mAb}$. This is clearly shown in the lower portion of Figure $2, A-C$, where the indicated sections of the records are displayed at higher time resolution. These results indicate that the inhibition of channel activity can be accounted for by a reduction in the number of active channels rather than by an alteration in single-channel characteristics.

The monovalent Fab fragments of both mAb 148 and mAb 168 affected neither the single ACh receptor channel activity (Table 4) nor the agonist-activated permeability response of reconstituted ACh receptor vesicles (Wan and Lindstrom, 1985). An antibody, $\mathrm{mAb} 7$, directed against a cytoplasmic domain of the $\delta$ subunit, and that probably crosslinks the cytoplasmic surfaces of $\gamma$ and $\delta$ subunits (Tzartos and Lindstrom, 1980,

Table 4. Effect of antireceptor mAbs on agonist-activated singlechannel currents of Torpedo ACh receptor in lipid bilayers

Percent inhibition of channel activity

$\begin{array}{lc}\begin{array}{l}\text { ACh receptor and } \\ \text { mAb preincubated } \\ \text { before membrane } \\ \text { assembly }\end{array} & \begin{array}{l}\text { MAb added during } \\ \text { periods of channel } \\ \text { activity }\end{array} \\ 19(n=37) & 0(n=10), \text { cis } \\ - & 0(n=7), \text { cis } \\ 20(n-40) & 0(n=4), \text { cis } \\ 63(n=32) & 44(n=34), \text { cis } \\ - & 0(n=4), \text { cis } \\ - & 100(n=7), \text { trans } \\ 0(n=4) & 0(n=4), \text { trans } \\ - & 30(n=10), \text { cis } \\ - & 100(n=6), \text { trans } \\ - & 20(n=5), \text { trans } \\ - & 0(n=3), \text { cis } \\ - & 0(n=10), \text { trans }\end{array}$

Inhibition of channel activity, as that illustrated in Fig. 2, is expressed as percent effectiveness ( $n=$ total number of experiments). cis and trans define the location of the antibody with respect to the compartment containing ACh. Other experimental conditions were as described in Methods. 


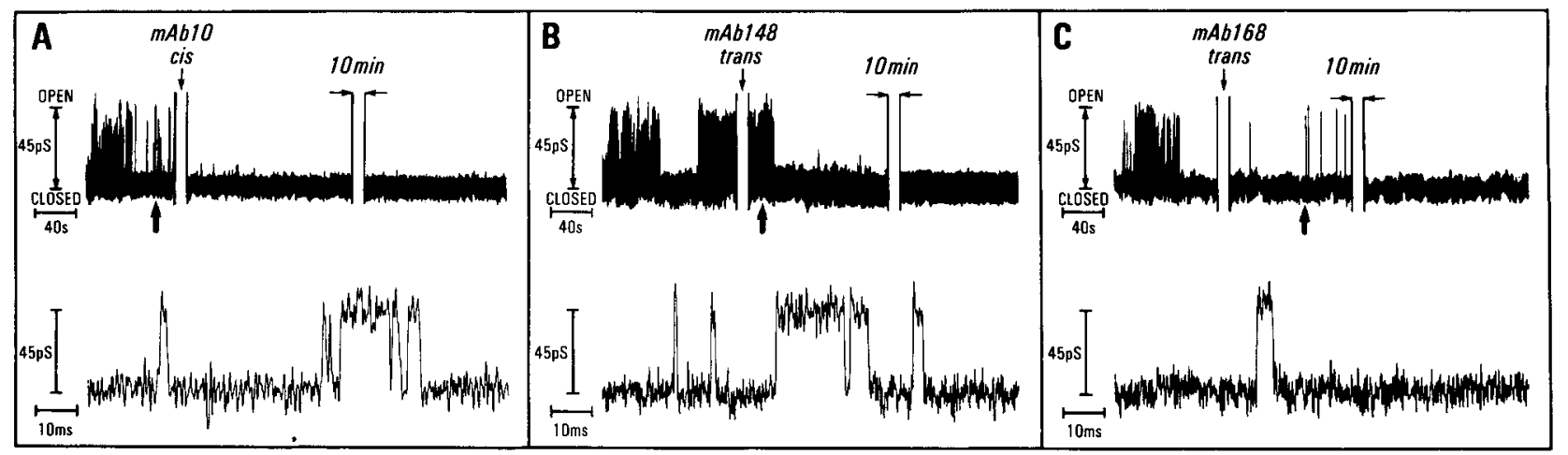

Figure 2. MAbs block of ACh receptor channels. Single ACh receptor channel currents were activated by $10 \mu \mathrm{M} A C h$ and recorded at $100 \mathrm{mV}$. The recordings were obtained from bilayers formed at the tip of patch pipets. $A$, MAb 10 inhibits single ACh receptor channel activity. The initial current shows a single ACh receptor open channel interrupted by many brief closings. At the arrow, mAb $10(0.2 \mu \mathrm{M}$, a 4 -fold molar excess with respect to ACh receptor) was added to the cis chamber. The ACh receptor channel activity was promptly inhibited. The lower panel of the figure displays the section of the record indicated by the arrow at higher time resolution (note the change in time calibration) to illustrate clearly resolved single channels after a previous addition of mAb $10(0.1 \mu \mathrm{M})$. The seal resistance was $5 \mathrm{G} \Omega$. B, MAb 148 inhibits single ACh receptor channel activity. The initial current shows bursts of channel openings separated by short and long quiescent periods. At the arrow, $3.8 \mu \mathrm{M}$ mAb 148 was added to the trans chamber. The ACh receptor channel activity was soon inhibited and remained blocked for more than 10 min. The ACh receptor concentration was $0.05 \mu \mathrm{M}$. The lower panel of the figure displays the segment of the record indicated by the arrow at higher time resolution. The records illustrate that the channel properties of the ACh receptor before and after addition of mAb 148 are virtually the same. The seal resistance was $6 \mathrm{G} \Omega$. C, MAb 168 inhibits single ACh receptor channel activity. At the arrow, $1.3 \mu \mathrm{M}$ mAb 168 was added to the trans chamber. The single $\mathrm{ACh}$ receptor channel was drastically inhibited. The ACh receptor concentration was $0.05 \mu \mathrm{M}$. The lower panel shows the section of the record indicated by the arrow at higher time resolution. The seal resistance was $7 \mathrm{G} \Omega$. All other conditions were as for Figure 1 .

1981), altered neither the single-channel conductance (Table 2) nor the lifetimes of the open ACh receptor channel, irrespective of the compartment to which it was added (Table 4). The results of this study are summarized in Table 4.

The mechanism of $\mathrm{mAb}$ inhibition of channel function is unknown. Inhibition cannot be accounted for by steric hindrance as introduced by binding the large immunoglobulin molecule on the $\mathrm{ACh}$ receptor, since $\mathrm{mAbs} 35$ and 6 , which bind to the MIR and crosslink ACh receptors (Conti-Tronconi et al. 1981; Fairclough et al., 1983; Lindstrom et al., 1983; Wan and Lindstrom, 1985), do not inhibit channel function. The inhibitory mAbs may act by crosslinking sites between adjacent subunits to prevent the sliding or rotation of subunits, thereby leading to an immobilized conformation of the ACh receptor. This inference is based on the fact that monovalent Fab fragments of the inhibitory mAbs (148 and 168) do not crosslink ACh receptor subunits and are noninhibitory.

It is clear that most Abs do not block function (see also Lindstrom et al., 1983; Wan and Lindstrom, 1985). This conclusion is valid for mAbs to the extracellular surface of $\alpha$ (i.e., near the $\mathrm{ACh}$ binding site) and for several mAbs that crosslink ACh receptor subunits. Therefore, the sites at which the rare inhibitory antibodies bind are evidently functionally important. As these binding sites are mapped on the primary structure of the $\mathrm{ACh}$ receptor, the functional role of these discrete domains may be identified. MAbs directed against the ACh binding site (Goldberg et al., 1983) and to a noncholinergic site (Donnelly et al., 1984) also inhibit the agonist-activated translocation of cations mediated by ACh receptors. The approach described here (see also Donnelly et al., 1984; Goldberg et al., 1983; Gonzalez-Ros et al., 1984), namely, the use of mAbs to probe $\mathrm{ACh}$ receptor function in conjunction with sitc-spccific mutagenesis (Mishina et al., 1985) and site-directed antibodies (Lindstrom et al., 1984; Neumann et al., 1984), should contribute additional strategic information toward a molecular mapping of structure-function relationships in the cholinergic receptor channel.

Note added in proof. The binding site for $\mathrm{mAb} 148$ has been determined to lie within the sequence 368-406 on the cytoplasmic surface of $\beta$ subunits (M. Ratnam, P. Sargent, V. Sarin, J. Fox, D. Le Nguyen, J. Rivier, M. Criado, and J. Lindstrom, unpublished observations). MAb 10 binds weakly to the sequence $360-370$, which is located on the cytoplasmic surface of $\alpha$ subunits (M. Ratnam, D. Le Nguyen, J. Rivier, P. Sargent, and J. Lindstrom, unpublished observations). It also binds weakly to a comparable region of $\beta$ subunits. Because mAb 10 binds weakly and only blocks receptor function when it is used at high concentrations, the site(s) through which it blocks function is (are) unclear.

\section{References}

Anholt, R., J. Lindstrom, and M. Montal (1981) Stabilization of acetylcholine receptor channels by lipids in cholate solution and during reconstitution in vesicles. J. Biol. Chem. 256: 4377-4387.

Anholt, R., D. R. Fredkin, T. Deerinck, M. Ellisman, M. Montal, and J. Lindstrom (1982) Incorporation of acetylcholine receptors into liposomes: Vesicle structure and acetylcholine receptor function. $\mathbf{J}$. Biol. Chem. 257: 7122-7134.

Blatt, Y., M. S. Montal, J. Lindstrom, and M. Montal (1984) Effect of antireceptor monoclonal antibodies on single channel currents of purified acetylcholine receptor reconstituted in lipid bilayers. Biophys. J. 45: Abstr. 311 a.

Boheim, G., W. Hanke, F. J. Barrantes, H. Eibl, B. Sakmann, G. Fels, and A. Maelicke (1981) Agonist-activated ionic channels in acetylcholine receptor reconstituted into planar lipid bilayers. Proc. Natl. Acad. Sci. USA 78: 3586-3590.

Changeux, J.-P., T. Heidmann, J. Popot, and A. Sobel (1979) Reconstitution of a functional acetylcholine regulator under defined conditions. FEBS Lett. 105: 181-187.

Changeux, J.-P., A. Devillers-Thiery, and P. Chemouilli (1984) Acetylcholine receptor: An allosteric protein. Science 225: 1335-1345.

Claudio, T., M. Ballivet, J. Patrick, and S. Heinemann (1983) Nucleotide and deduced amino acid sequences of Torpedo californica acetylcholine receptor $\gamma$ subunit. Proc. Natl. Acad. Sci. USA 80: 1111-1115.

Conti-Tronconi, B., S. Tzartos, and J. Lindstrom (1981) Monoclonal antibodies as probes of acetylcholine receptor structure: 2 . Binding to native receptor. Biochemistry 20:2181-2191.

Criado, M., S. Hochschwender, V. Sarin, L. J. Fox, and J. Lindstrom (1985a) Evidence for unpredicted transmembrane domains in acetylcholine receptor subunits. Proc. Natl. Acad. Sci. USA 82: 20052008.

Criado, M., V. Sarin, J. L. Fox, and J. Lindstrom (1985b) Structural 
localization of the sequence $\alpha 235-242$ of the nicotinic acetylcholine receptor. Biochem. Biophys. Res. Commun. 128: 864-871.

Devillers-Thiery, A., J. Giraudat, M. Bentaboulet, and J. P. Changeux (1983) Complete mRNA coding sequence of the acetylcholine binding $\alpha$-subunit of Torpedo marmorata acetylcholine receptor: A model for the transmembrane organization of the polypeptide chain. Proc. Natl. Acad. Sci. USA 80: 2067-2071.

Donnelly, D., M. Mihovilovic, J. M. Gonzalez-Ros, J. A. Ferragut, D. Richman, and M. Martinez-Carrion (1984) A non-cholinergic sitedirected monoclonal antibody can impair agonist-induced ion flux in Torpedo californica acetylcholine receptor. Proc. Natl. Acad. Sci. USA 81: 7999-8003.

Fairclough, R. H., J. Finer-Moore, R. A. Love, D. Kristofferson, P. J. Desmeules, and R. M. Stroud (1983) Subunit organization and structure of an acetylcholine receptor. Cold Spring Harbor Symp. Quant. Biol. 48: 9-20.

Fletcher, R. (1971) A modified Marquardt subroutine for non-linear least squares. AERE Rep. R6799.

Froehner, S. C. (1981) Identification of exposed and buried determinants of the membrane-bound acetylcholine receptor from Torpedo californica. Biochemistry 20: 4905-4915.

Goldberg, G., D. Mochly-Rosen, S. Fuchs, and Y. Lass (1983) Monoclonal antibodies modify acetylcholine-induced ionic channel properties in cultured chick myoballs. J. Membr. Biol. 76: 123-128.

Gonzalez-Ros., J. M., A. Paraschos, and M. Martinez-Carrion (1980) Reconstitution of functional membrane-bound acetylcholine receptor from isolated Torpedo californica receptor protein and electroplax lipids. Proc. Natl. Acad. Sci. USA 77: 1796-1800.

Gonzalez-Ros, I. M., J. A. Ferragut, and M. Martinez-Carrion (1984) Binding of anti-acetylcholine receptor antibodies inhibits the acetylcholine receptor mediated cation flux. Biochem. Biophys. Res. Commun. 120: 368-375.

Gullick, W. J., and J. M. Lindstrom (1983) Mapping the binding of monoclonal antibodies to the acetylcholine receptor from Torpedo californica. Biochemistry 22: 3312-3320.

Hochschwender, S., L. Langeberg, D. Schneider, and J. Lindstrom (1985) Production of rat $\times$ mouse hybridomas for the study of the nicotinic acetylcholine receptor. In Hybridomas in Biotechnology and Medicine, T. Springer, ed., pp. 223-238. Plenum, New York.

Huganir, R. L., M. A. Schell, and E. Racker (1979) Reconstitution of the purified acetylcholine receptor from Torpedo californica. FEBS Lett. 108: 155-160.

Kao, P. W., A. J. Dwork, R.-R. J. Kaldany, M. L. Silver, J. Wideman, S. Stein, and A. Karlin (1984) Identification of the $\alpha$ subunit halfcystine specifically labeled by an affinity reagent for the acetylcholine receptor binding site. J. Biol. Chem. 259: 11662-11665.

Labarca, P., J. Lindstrom, and M. Montal (1984a) Acetylcholine receptor in planar lipid bilayers: Characterization of the channel properties of the purified nicotinic acetylcholine receptor from Torpedo californica reconstituted in planar lipid bilayers. J. Gen. Physiol. 83: 473-496.

Labarca, P., J. Lindstrom, and M. Montal (1984b) The acetylcholine receptor channel from Torpedo californica has two open states. J. Neurosci. 4: 502-507.

Labarca, P., J. Rice, D. Fredkin, and M. Montal (1985a) Kinetic analysis of channel gating: Application to the cholinergic receptor channel and to the chloride channel from Torpedo californica. Biophys. J. 47: 469-478.

Labarca, P., M. S. Montal, J. Lindstrom, and M. Montal (1985b) The occurrence of long openings in the purified cholinergic receptor channel increases with acetylcholine concentration. J. Neurosci.

Lindstrom, J., R. Anholt, B. Einarson, A. Engel, M. Osame, and M. Montal (1980) Purification of acetylcholine receptors, reconstitution into lipid vesicles, and study of agonist-induced cation channel regulation. J. Biol. Chem. 255: 8340-8350.

Lindstrom, J., B. Einarson, and S. Tzartos (1981a) Production and assay of antibodies to acetylcholine receptors. Methods Enzymol. Immunochem. Techn. 74: 432-460.

Lindstrom, J. M., S. J. Tzartos, and W. J. Gullick (1981b) Structure and function of acetylcholine receptor molecule studies using monoclonal antibodies. Ann. NY Acad. Sci. 377: 1-19.

Lindstrom, J., S. Tzartos, W. Gullick, S. Hochschwender, L. Swanson, P. Sargent, M. Jacob, and M. Montal (1983) Use of monoclonal antibodies to study acetylcholine receptors from electric organs, muscle, and brain and the autoimmune response to receptor in myasthenia gravis. Cold Spring Harbor Symp. Quant. Biol. 48: 89-99.

Lindstrom, J., M. Criado, S. Hochschwender, J. L. Fox, and V. Sarin (1984) Immunochemical tests of acetylcholine receptor subunit models. Nature 311: 573-575.

Mishina, M., T. Kurosaki, T. Tobimatsu, Y. Morimoto, M. Noda, T. Yamamoto, M. Terao, J. Lindstrom, T. Takahashi, M. Kuno, and S. Numa (1984) Expression of functional acetylcholine receptor from cloned cDNAs. Nature 307: 604-608.

Mishina, M., T. Tobimatsu, K. Imoto, K. Tanaka, Y. Fujita, K. Fukuda, M. Kurasaki, H. Takahashi, Y. Morimoto, T. Hirose, S. Inayama, T. Takahashi, M. Kuno, and S. Numa (1985) Location of functional regions of acetylcholine receptor $\alpha$-subunit by site-directed mutagenesis. Nature 313: 364-369.

Montal, M., P. Labarca, D. R. Fredkin, B. A. Suarez-Isla, and J. Lindstrom (1984) Channel properties of the purified acetylcholine receptor from Torpedo californica reconstituted in planar lipid bilayer membranes. Biophys. J. 45: 165-174.

Nelson, N., R. Anholt, J. Lindstrom, and M. Montal (1980) Reconstitution of purified acetylcholine receptors with functional ion channels in planar lipid bilayers. Proc. Natl. Acad. Sci. USA 77: 30573061 .

Neumann, D., M. Fridkin, and S. Fuchs (1984) Anti-acetylcholine receptor response achieved by immunization with a synthetic peptide from the receptor sequence. Biochem. Biophys. Res. Commun. 121: 673-679.

Noda, M., H. Takahashi, T. Tanabe, M. Toyosato, Y. Furutani, T. Hirose, M. Asai, S. Inayama, T. Miyata, and S. Numa (1982) Primary structure of $\alpha$-subunit precursor of Torpedo californica acetylcholine receptor deduced from cDNA sequences. Nature 299: 793797.

Noda, M., H. Takahashi, T. Tanabe, M. Toyosato, S. Kikyotani, T. Hirose, M. Asai, H. Takashima, S. Inayama, T. Miyata, and S. Numa (1983a) Primary structures of $\beta$ - and $\delta$-subunit precursors of Torpedo californica acetylcholine receptor deduced from cDNA sequences. Nature 301: 251-255.

Noda, M., H. Takahashi, T. Tanabe, M. Toyosato, S. Kikyotani, Y. Furutani, T. Hirose, H. Takashima, S. Inayama, T. Miyata, and S. Numa (1983b) Structural homology of Torpedo californica acetylcholine receptor subunits. Nature 302: 528-532.

Sargent, P. B., B. E. Hedges, L. Tsavaler, L. Clemmons, S. Tzartos, and J. M. Lindstrom (1984) Structure and transmembrane nature of the acetylcholine receptor in amphibian skeletal muscle as revealed by cross-reacting monoclonal antibodies. J. Cell Biol. 98: 609-618.

Schindler, H., F. Spillecke, and E. Neumann (1984) Different channel properties of Torpedo acetylcholine receptor monomers and dimers reconstituted in planar membranes. Proc. Natl. Acad. Sci. USA 81: 6222-6226.

Strader, C. D., and M. A. Raftery (1980) Topographic studies of Torpedo acetylcholine receptor subunits as a transmembrane complex. Proc. Natl. Acad. Sci. USA 77: 5807-5811.

Strader, C. B. D., J.-P. Revel, and M. A. Raftery (1979) Demonstration of the transmembrane nature of the acetylcholine receptor by labeling with anti-receptor antibodies. J. Cell. Biol. 83: 499-510.

Suarez-Isla, B. A., K. Wan, J. Lindstrom, and M. Montal (1983) Single channel recordings from purified acetylcholine receptors reconstituted in bilayers formed at the tip of patch pipets. Biochemistry $22: 2319$ 2323.

Tank, D. W., R. L. Huganir, P. Greengard, and W. W. Webb (1983) Patch-recorded single-channel currents of the purified and reconstituted Torpedo acetylcholine receptor. Proc. Natl. Acad. Sci. USA 80: 5129-5133.

Tarrab-Hazdai, R., B. Geiger, S. Fuchs, and A. Amsterdam (1978) Localization of acetylcholine receptor in excitable membrane from the electric organ of Torpedo: Evidence for the exposure of receptor antigenic sites on both sides of the membrane. Proc. Natl. Acad. Sci. USA 75: 2497-2501.

Tzartos, S. J., and J. M. Lindstrom (1980) Monoclonal antibodies used to probe acetylcholine receptor structure: Localization of the main immunogenic region and detection of similarities between subunits. Proc. Natl. Acad. Sci. USA 77: 755-759.

Tzartos, S., and J. Lindstrom (1981) Production and characterization of monoclonal antibodies for use as probes of acetylcholine receptors. In Monoclonal Antibodies in Endocrine Research, R. Fellows and G. Eisenbarth, eds. pp. 69-86, Raven, New York.

Tzartos, S. J., D. E. Rand, B. L. Einarson, and J. M. Lindstrom (1981) 
Mapping of surface structure of Electrophorus acetylcholine receptor using monoclonal antibodies. J. Biol. Chem. 256: 8635-8645.

Tzartos, S. J., M. E. Seybold, and J. M. Lindstrom (1982) Specificity of antibodies to acetylcholine receptors in sera from myasthenia gravis patients measured by monoclonal antibodies. Proc. Natl. Acad. Sci. USA 79: 188-192.

Tzartos, S., L. Langeberg, S. Hochschwender, L. Swanson, and J. M. Lindstrom (in press) Characteristics of monoclonal antibodies to denatured Torpedo and to native calf acetylcholine receptors: Species, subunit, and region specificity. J. Neuroimmunol.

Wan, K. K., and J. M. Lindstrom (1985) Effects of monoclonal antibodies on the function of acetylcholine receptors purified from Torpedo californica and reconstituted into vesicles. Biochemistry 24:12121221.
Wennogle, L. P., and J.-P. Changeux (1980) Transmembrane orientation of proteins present in acetylcholine receptor-rich membranes from Torpedo marmorata studied by selective proteolysis. Eur. J. Biochem. 106: 381-393.

Wu, W. C. S., and M. A. Raftery (1979) Carbamylcholine-induced rapid cation efflux from reconstituted membrane vesicles containing purified acetylcholine receptor. Biochem. Biophys. Res. Commun. 89: 26-35.

Young, E. F., E. Ralston, J. Blake, J. Ramachandran, Z. W. Hall, and R. M. Stroud (1985) Topological mapping of acetylcholine receptor: Evidence for a model with five transmembrane segments and a cytoplasmic $\mathrm{COOH}$-terminal peptide. Proc. Natl. Acad. Sci. USA 82: 626-630. 